\title{
CLASSIFICATION AND EVALUATION OF SOILS REPRESENTING THE GEOMORPHIC UNITS IN THE NORTHWESTERN COAST OF SINAI, EGYPT
}

\author{
Ghada A. Abd El-Kader \\ Soils, water and Environment Research Inst. A.R.C. Giza
}

Received: Dec. 26, 2016

Accepted: Apr. 10, 2017

\begin{abstract}
Northwestern coast of Sinai Peninsula is one from the prospective areas for agriculture expansion in Egypt. The aim of this work is to study characteristics, classification and evaluation of soils representing the geomorphic units of this area.

For this purpose, fifteen soil profiles were chosen representing the main geomorphic units of this area namely, Sabkha, Coastal plain, Elevated sand dunes, El-Tina plain and Western coastal plain.

The soil profiles were morphological described and samples were collected for laboratory analyses.

According to Soil Survey Staff (2014), the studied soils were classified up to sub-great group level into the two orders of Aridisols and Entisols and three suborders namely, Salids, Gypsides and Psamments.

The studied soils were evaluated for their current suitability for agriculture which they categorized into two classes namely, marginally suitable $\left(S_{3}\right)$ and not suitable $(N)$. These soils are suffering from different limitations of wetness, texture, depth, gypsum and salinity and alkalinity with different intensity. The severity of these limitations could be corrected by application of organic and inorganic amendments and salt leaching as well as modern irrigation systems (drip and sprinkler). Accordingly, the potential suitability of the most studied soils could be improved to moderately suitable $\left(S_{2}\right)$ and marginally suitable $\left(S_{3}\right)$.

Moreover the suitability of the studied soils for 13 selected main crops are evaluated. The results indicated that the soils of Sabkha, El Tina plain and Western coastal plain with their current situation are not suitable for growing these crops. The potential suitability for these crops could be improved according to the satisfaction conditions between different properties of the studied soils and crop requirements.
\end{abstract}

Key words: Geomorphic units, soil classification, land evaluation, suitability for agriculture and suitability for crops.

\section{INTRODUCTION}

Egypt is one of the most over population countries relatively to its cultivated area. The horizontal extension in cultivated area is one of the agricultural policy to face the urgent needs for increasing food production.

El-Salam canal is one of the main promising projects for reusing the drainage waters in irrigation, namely Hauds and ElSerur drains after mixing their water with Nile water delivered from Damietta branch. This Canal was designated to irrigate about 600.000 Feddands, among them the soils located south El-Manzala and El-Bardawil lakes which characterized by high salinity and AlKalinity. Many of the newly developed lands are situated in the northwestern parts of Sinai Peninsula. The capability evaluation of soils in this area is therefore, an essential action in order to maintain the sustainable development of effort and investment as well as the sustainable usage of the soils.

The study area is located in the western north of Sinai coastal plain and south ElBardawil lake. It extends between longitudes $23^{\circ} 18^{\prime}$ and $33^{\circ} 30^{\prime}$ East, and latitudes $31^{\circ}$ 23 and $30^{\circ} 30$ North with a total area of about $1500 \mathrm{~km}^{2}$ (360000 Feddans) Fig. (1). 
This area includes different land forms namely, Coastal sand beach, individual Sabkhas, mobile elevated sand dunes, deflated sand terrain, El-Tina plain and western coastal plain (Dames and Moore, 1985). The area formed in the latter part of the Miocene and beginning of Pliocene periods (Henry and Chorowicz, 1987). The surface of the study area essentially occupied by formation of the Quaternary and Holocene epochs (Said, 2000).

This area has a good potential for agricultural development due to the available water for irrigation comining from El-Shiekh Gaber Canal in eastern side of Suez Canal. This water with total salinity of about $825 \mathrm{mg} / \mathrm{L}$ is enough to irrigate about 400.000 Feddans in this region.
The aim of the current investigation is to study the morphological, Physical and chemical characteristics of soils representing the northwestern coastal plain of Sinai Peninsula. In addition, soil classification, land evaluation and suitability for growing main crops were performed.

\section{MATERIALS AND METHODS}

Based on the geomorphic information given by Dames and Moore (1985), fifteen soil profiles were chosen to represent different geomorphic units in the study area Fig. (2). These profiles was morphological described according to FAO (2006), and the data are given in Table (1). Forty-nine soil samples representing the different morphological variations throughout the entire profiles were collected, air-dried, crushed and sieved through a $2 \mathrm{~mm}$ sieve.

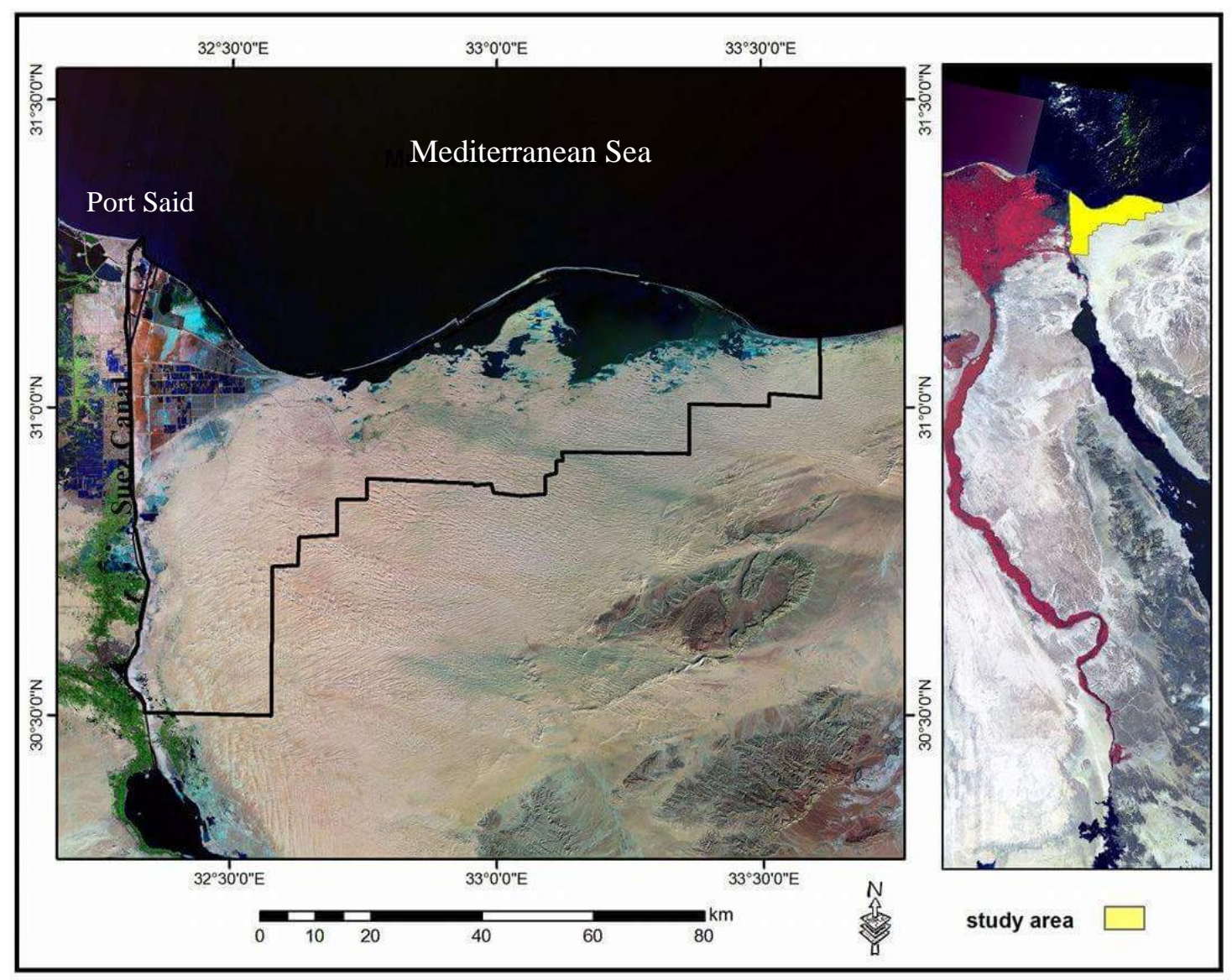

Fig. (1): Location of the study area 


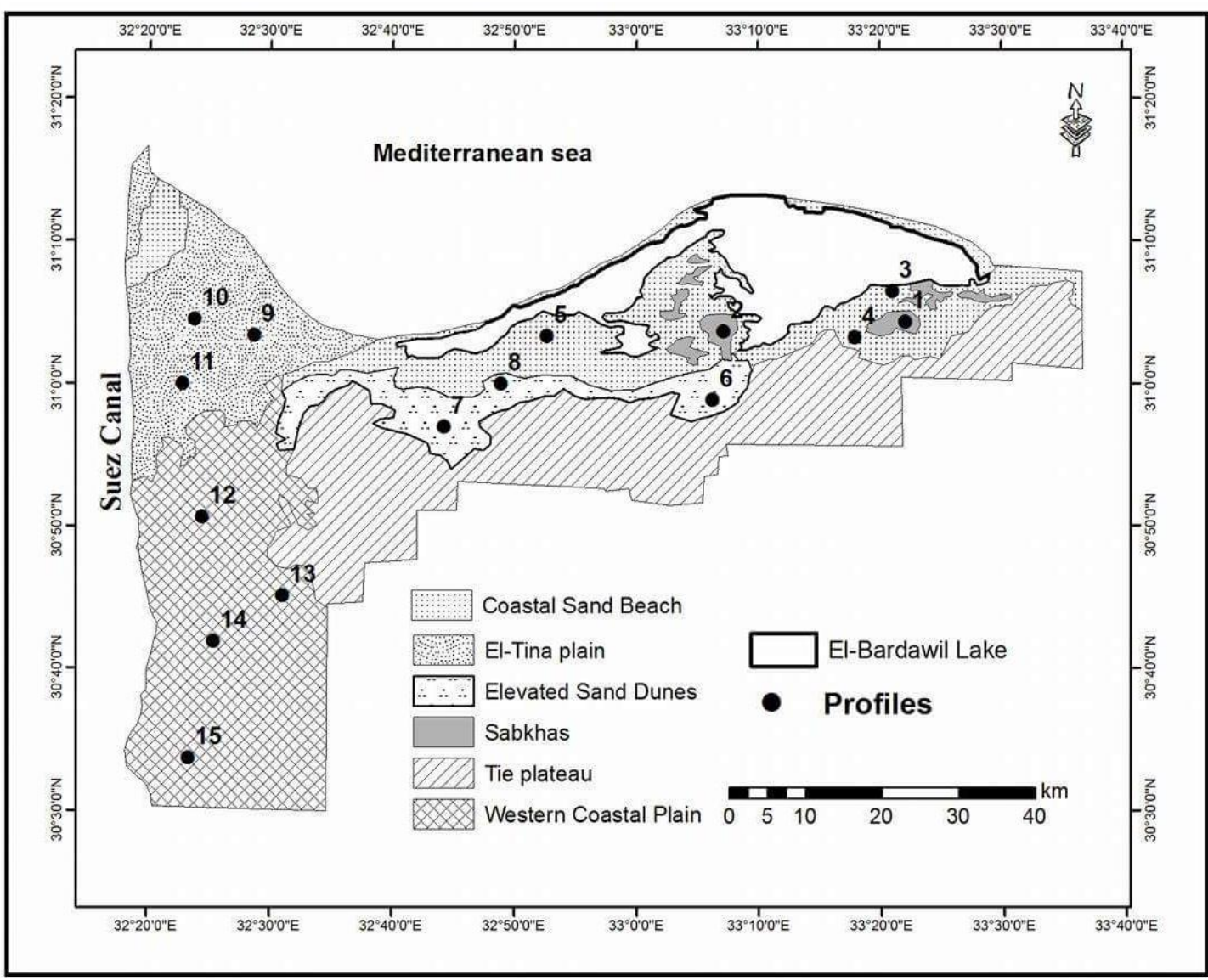

Fig. (2): Geomorphic Units and Profiles Locations

Representative soil samples were analyzed according to the methods outlined by Burt (2004), and the results are presented in Table (2). The soils were classified according to Soil Survey Staff (2014). The evaluation of land suitability for agriculture was performed according to Sys and Verheye (1978). Also, the suitability of studied soils for growing certain main crops were obtained using the system of Sys et al., (1993).

\section{RESULTS AND DISCUSSION}

The morphological description of soil profiles representing the geomorphic units of the studied area are shown in Table (1). The physicochemical properties of these profiles are presented in Table (2). Characteristics of the soils representing each geomorphic unit can be discussed as follows.

\section{Soils of Sabkha}

Sabkha unit forms discontinuous patches along east-west direction. It divided into dry and wet Sabkhas. The surface of wet Sabkha is almost flat and characterized by salty vegetation. Surface salt crust is also found mixed with some shell fragments. Dry Sabkha occupy wide area and characterized by almost flat surface covered with $3 \mathrm{~cm}$ thick fine textured salt crust.

This geomorphic unit was represented by profiles 1 and 2, which was located south of El-Bardawil lake. The soil surface is almost flat with gently undulating and covered with salt crust and drift sand. Soil color varied from gray (10 YR 6/1) to light brownish gray (10 YR 6/2) in dry status. While moist color ranged from grayish brown (10 YR 5/2) to brown (10 YR 5/3). Soil texture is sandy throughout the entire profiles depths. The 


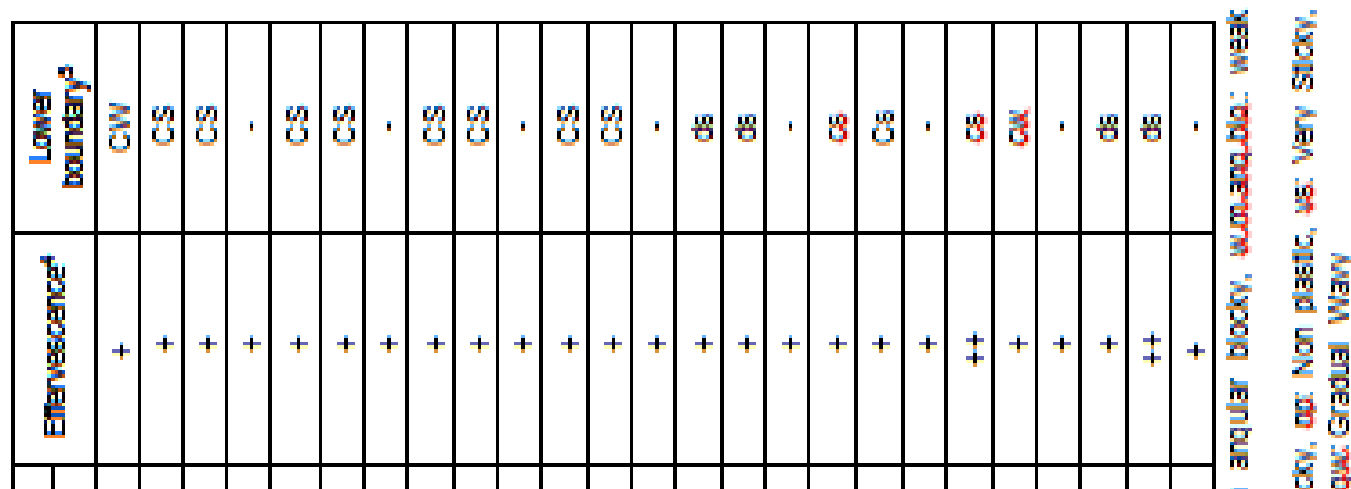

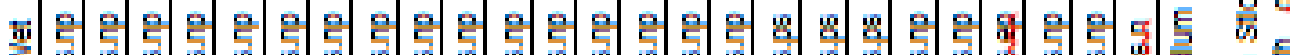

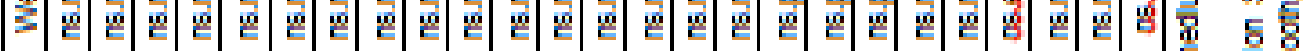

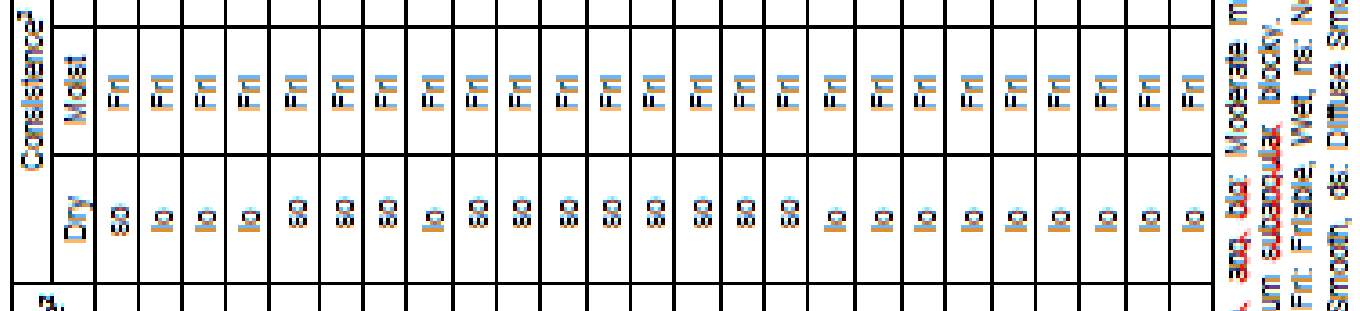

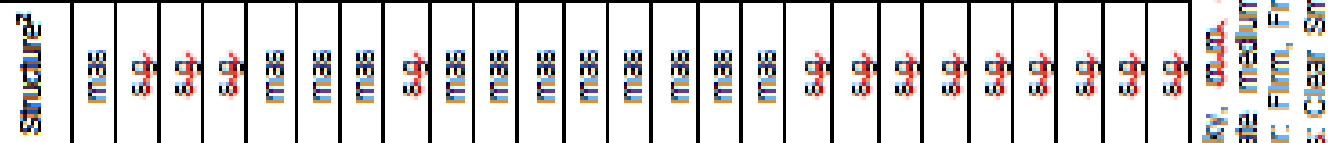

च บ่ 站

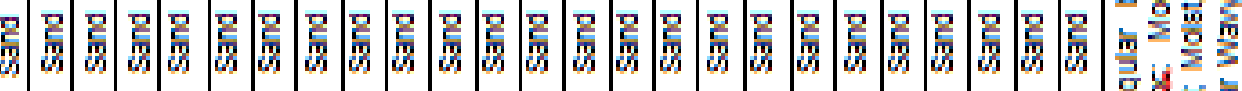

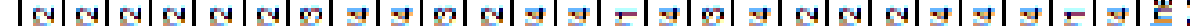

ธ

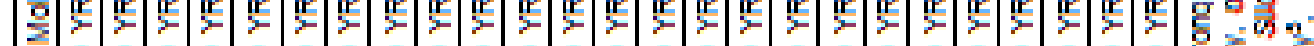

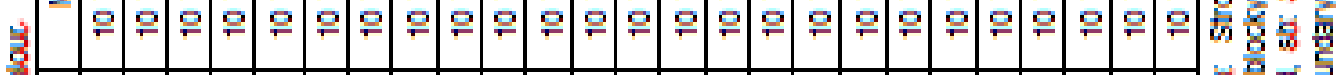

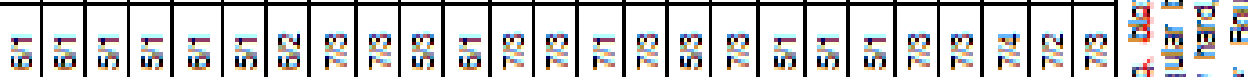

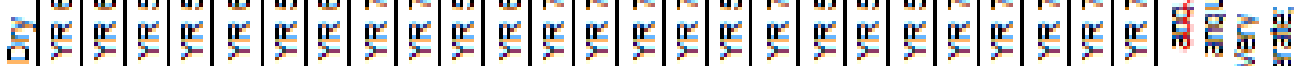

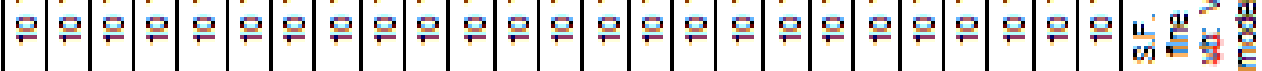

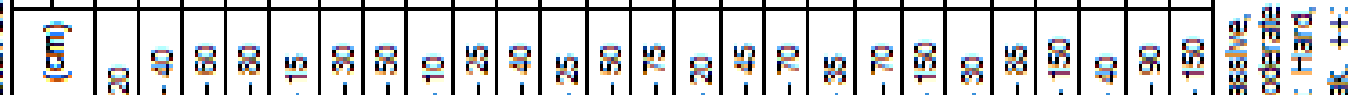

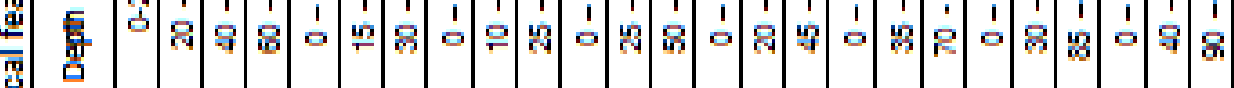

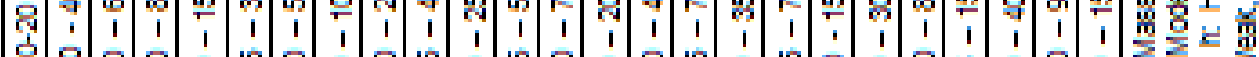

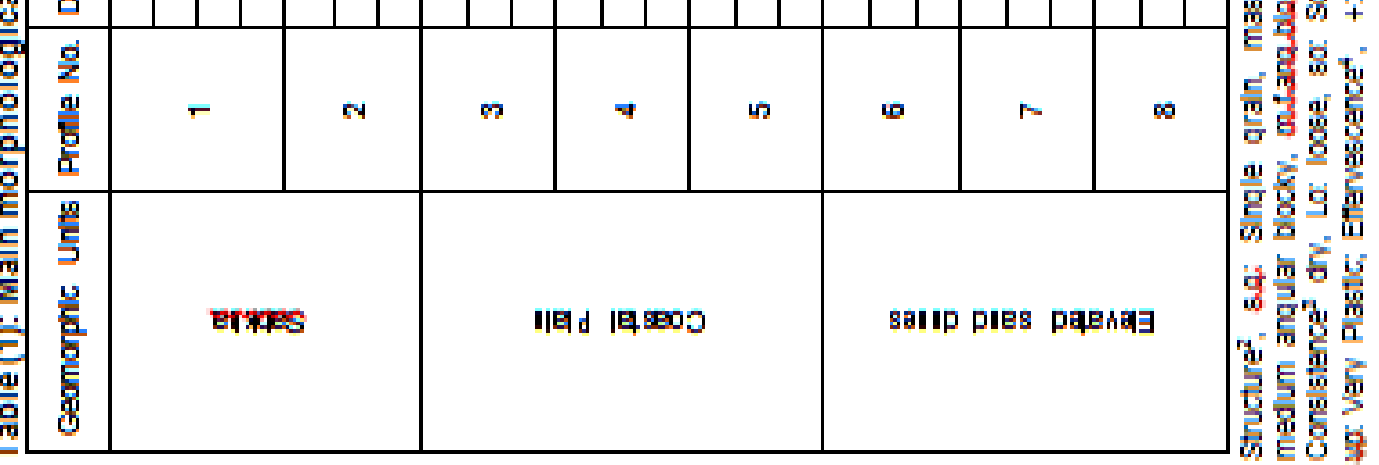




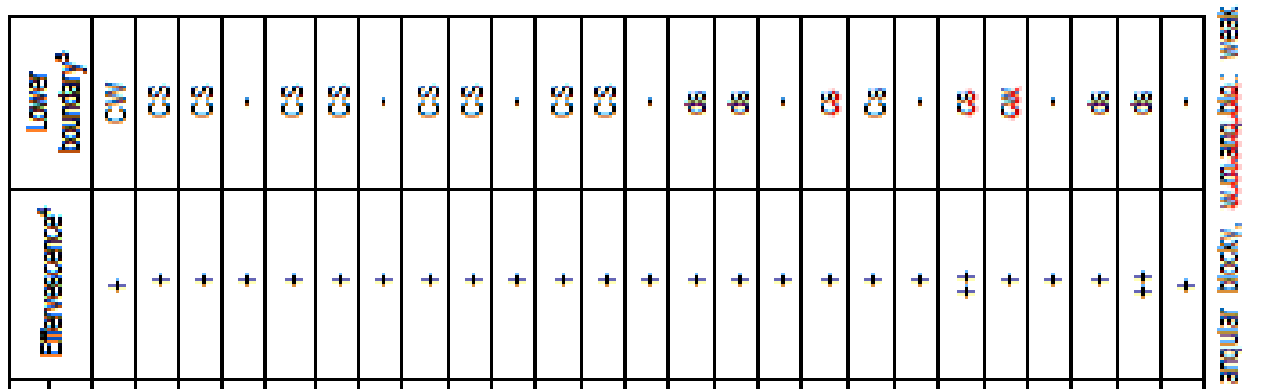

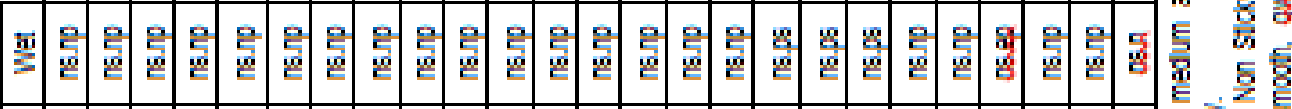

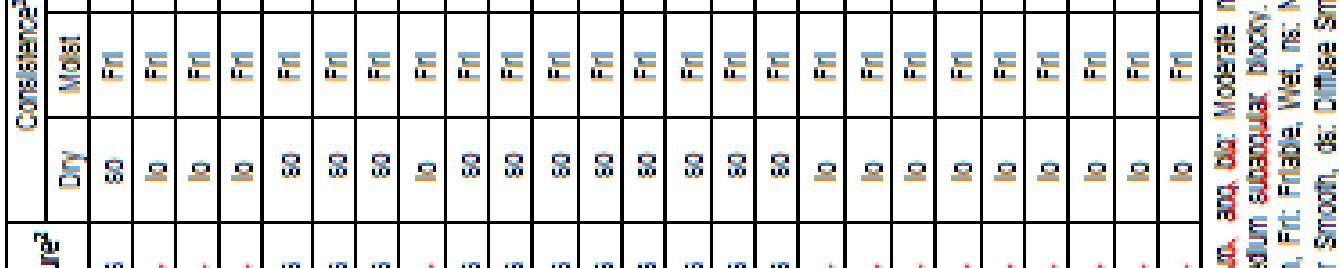

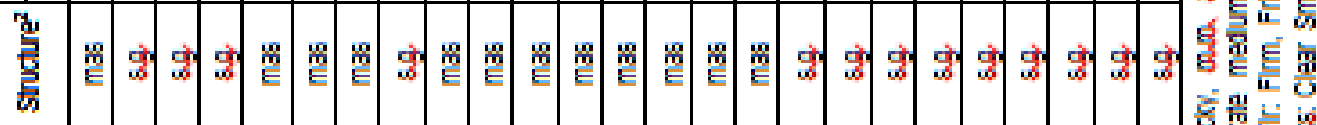

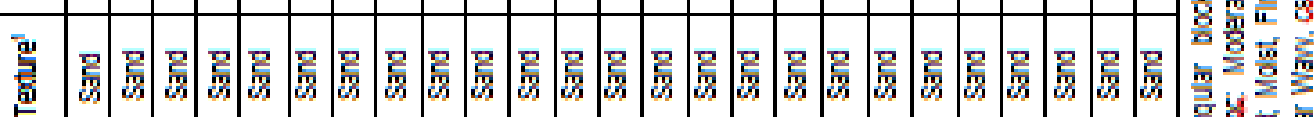

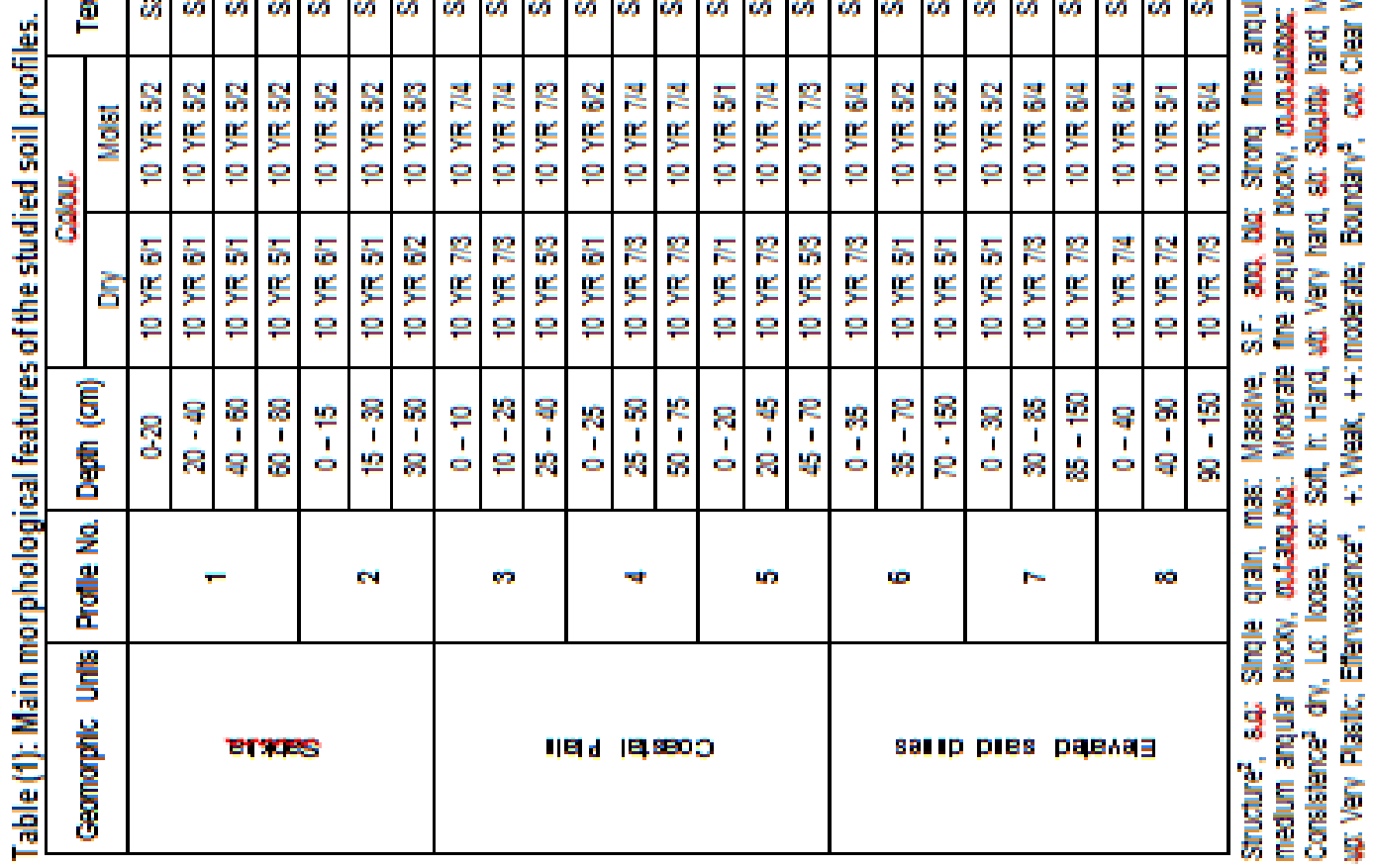




\begin{tabular}{|c|c|c|c|c|c|c|c|c|c|c|c|c|c|c|c|c|c|c|c|c|c|}
\hline 产要 & ธิ & 형 & & 1 & & 部 & . & के & 蜟 & 解 & ' & 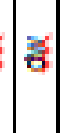 & 1 & क & क्ष & . & 3 & का. & 18 & 8 & 1 \\
\hline 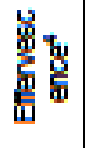 & + & $\ddagger$ & $\ddagger \ddagger$ & $\ddagger+$ & + & $+\ddagger$ & $\mp$ & + & + & ++ & ++ & + & + & + & $\mp$ & + & + & $+\mp$ & $\neq$ & + & + \\
\hline 章 & 이 & హี & 舟 & 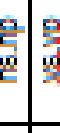 & 蛋 & 客 & a & 愛 & 愛: & 秀 & $\begin{array}{l}\text { 采 } \\
3\end{array}$ & $\begin{array}{l}\text { 은 } \\
\text { 至 }\end{array}$ & $\begin{array}{l}\text { 둘 } \\
\text { 至 }\end{array}$ & 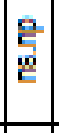 & \begin{tabular}{|l|} 
문 \\
을
\end{tabular} & 웓 & $\begin{array}{l}\text { 를 } \\
\text { क }\end{array}$ & 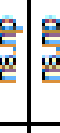 & 둘 & & $\begin{array}{l}\text { ? } \\
\text { 을 }\end{array}$ \\
\hline 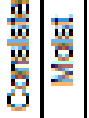 & 든 & 怘 & 든. & 인 & 证 & $=\mid \begin{array}{l}\frac{4}{4} \\
>\end{array}$ & $\mid \begin{array}{l}\text { in } \\
> \\
>\end{array}$ & 는 & 는 & 는 & 는 & 든 & 든 & 든 & 든 & 든 & 든 & 든 & 든 & 든 & 든 \\
\hline 동 & 웅 & 도 & $=\leq$ & o) $=$ & $==$ & $=\$$ & ॠ & $=$ & $=\leq$ & $=\$$ & 8 으 & 으 & 으 & 으 & 으 & 으 & 으 & 0 으 & 8 & 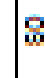 & 8 \\
\hline 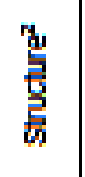 & 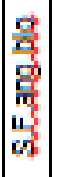 & 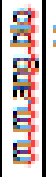 & 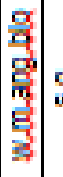 & (8) & 营 & 索 & 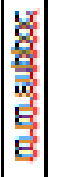 & 兽 & 甾 & 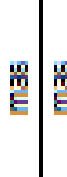 & 量 & g) & & 항 & के & के & के & & 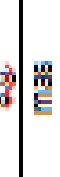 & 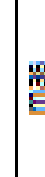 & 兽 \\
\hline
\end{tabular}

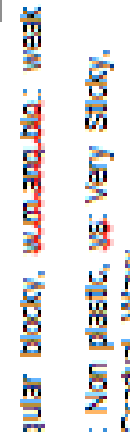

है

훌

它客

궁해

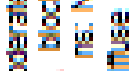

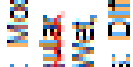
영응 $\geq$ ig

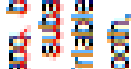

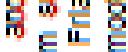
을 का है

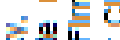
है

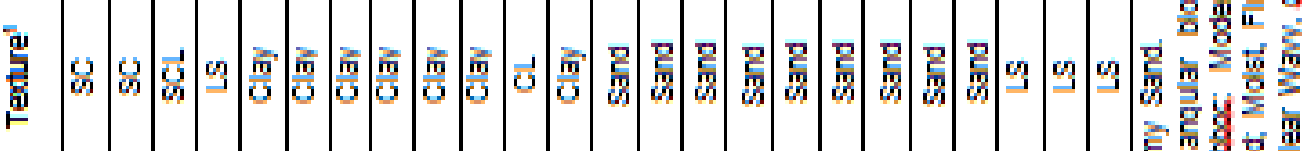

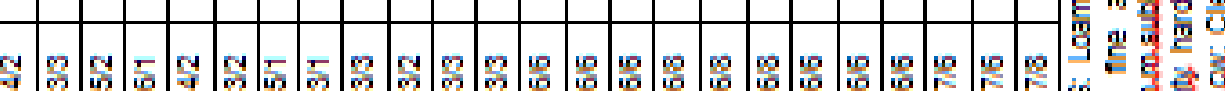
F.

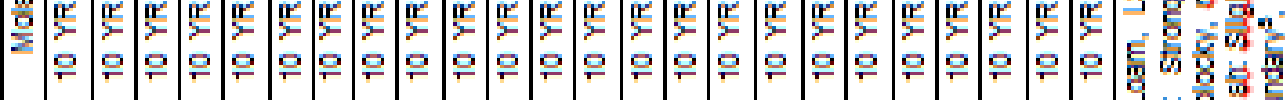

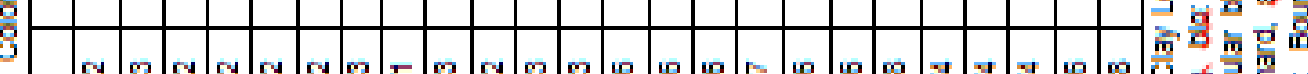
녕

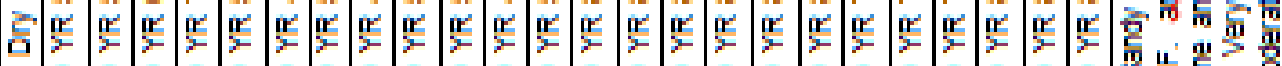

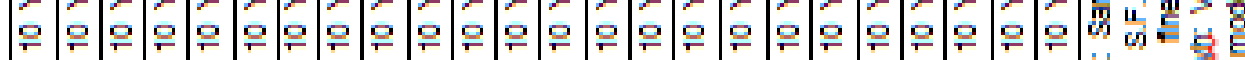

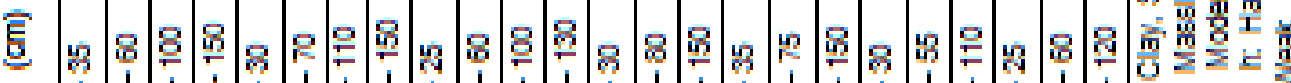

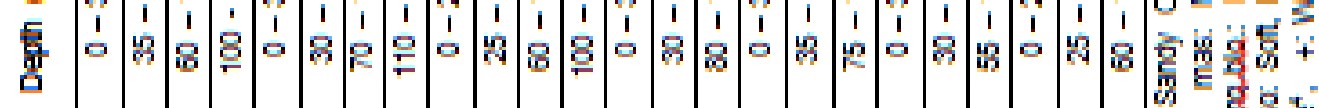

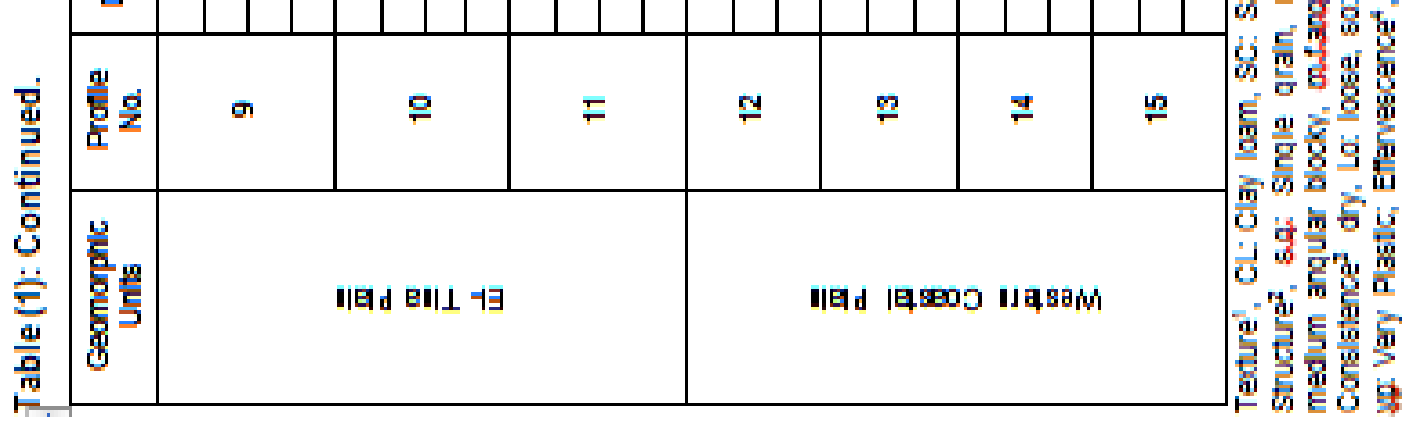




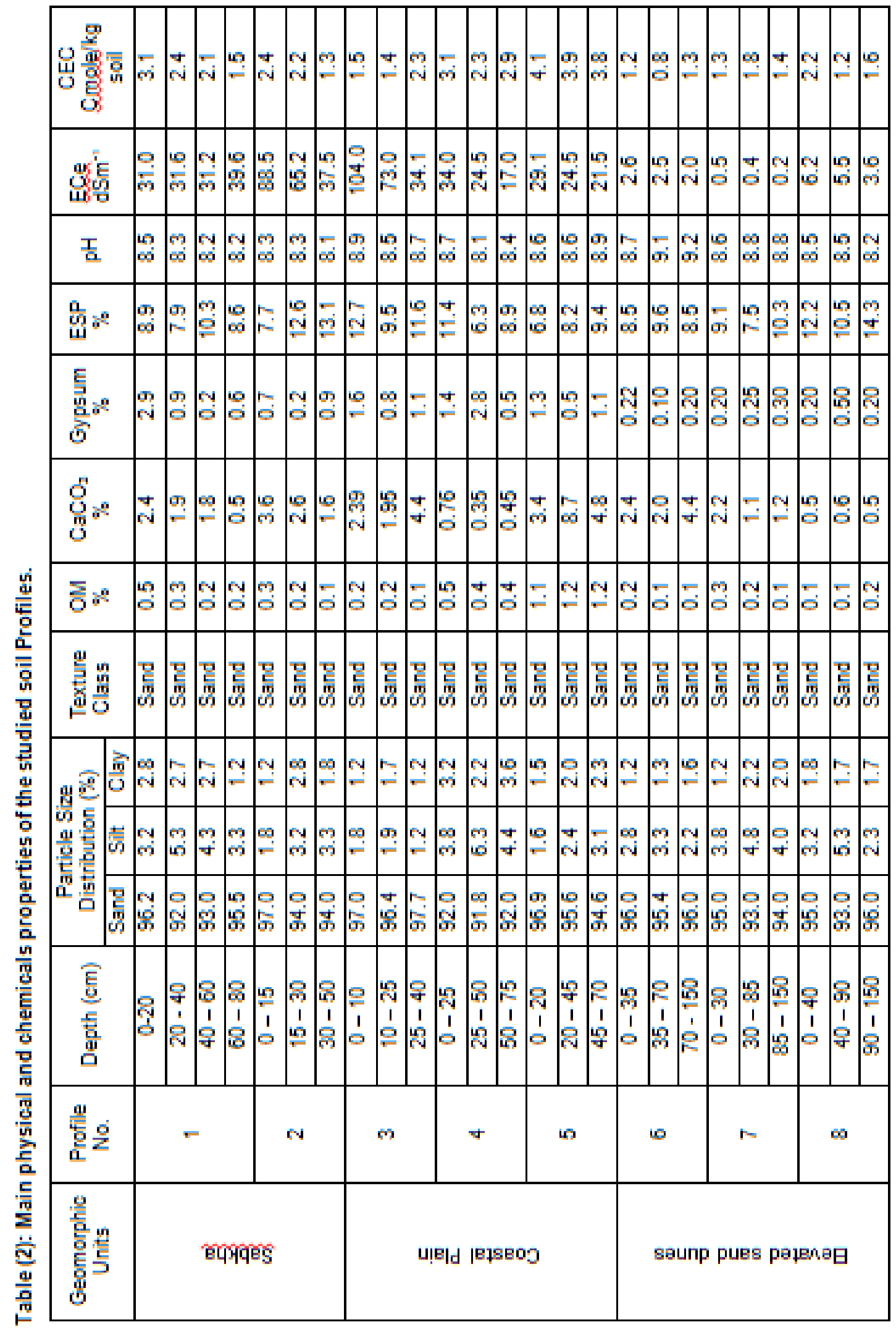




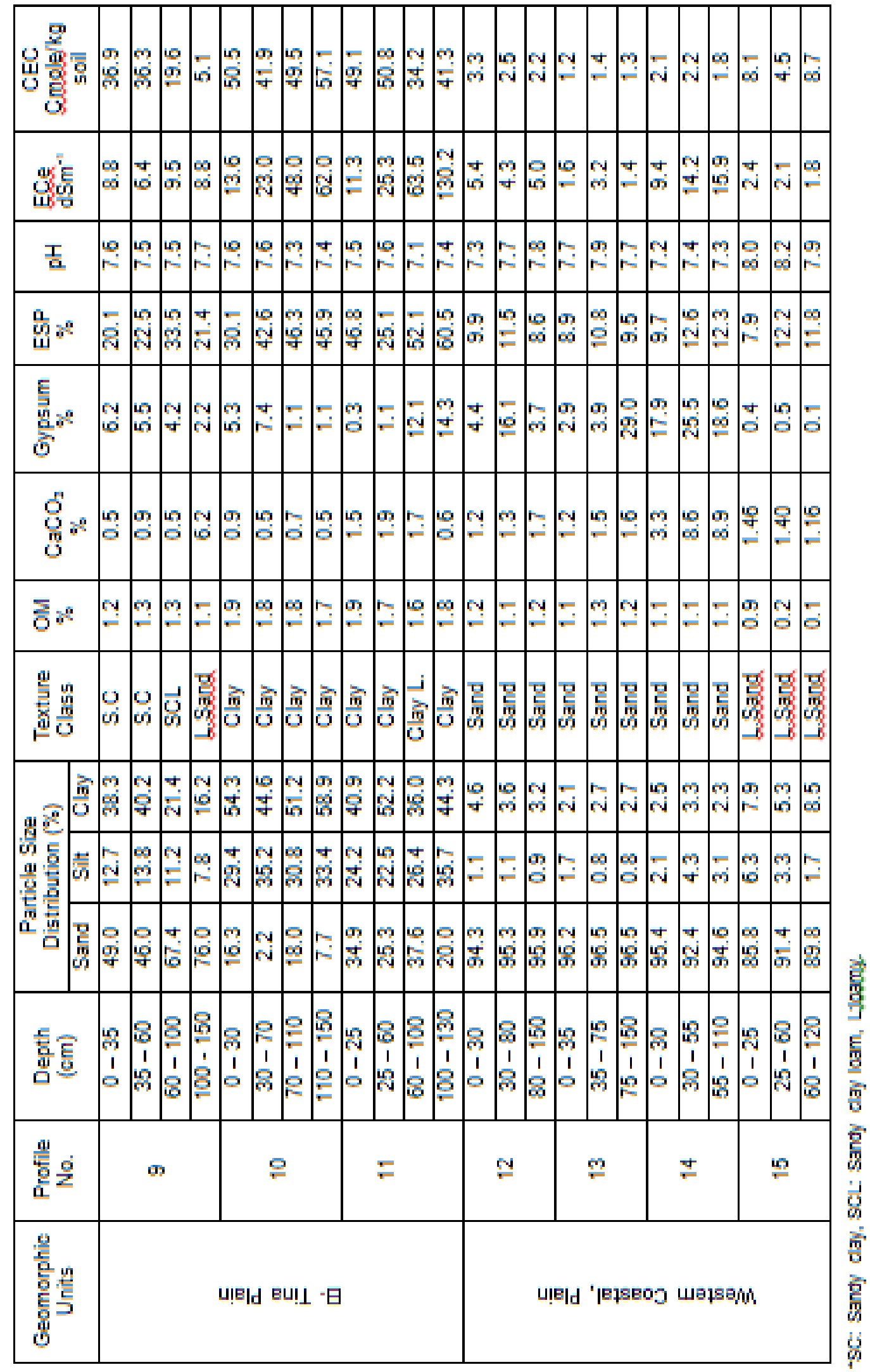


soils are moderately to strongly alkaline which their $\mathrm{pH}$ values ranged from 8.1 to 8.5. These soils are strongly to extremely saline, which their ECe values ranged between 31.0 and $88.5 \mathrm{dSm}-1$. Organic matter content is very low $(<0.5 \%) . \mathrm{CaCO}_{3}$ content ranged from 0.5 to $3.6 \%$ and decreased with soil depth. Gypsum content varied in narrow limits from 0.2 to $2.9 \%$. CEC ranged from 1.3 to $3.1 \mathrm{C}$ mole $\mathrm{Kg}^{-1}$. The ESP values were less than $15 \%$ indicating non-sodic status.

\section{Soils of Coastal Plain :}

The coastal plain geomorphic unit extends from east to west just parallel to the Mediterranean coast with a complex offshore bass. It has almost flat surface with variable width, not exceeding $5 \mathrm{~m}$. The inland side of this beach is broken by low sand accumulation, stripped by sand ripples. It is essentially composed of loses sand mostly affected by salinity due to seawater intrusion.

The soils of this unit are represented by three soil profiles (3,4 and 5). Data in Tables (1 and 2) show that these soils have gently undulating and undulating topography. Soil dry color ranged from gray (10 YR 5/1) to light yellowish brown (10 YR $6 / 4)$. While moist color varied from gray (10 YR 5/1) and very pale brown (10 YR 7/4). They have sandy texture throughout the entire profiles depths. Soil $\mathrm{pH}$ varied from 8.1 to 8.9 indicating moderately to strongly alkaline reaction. The soils are strongly to very extremely saline which have $\mathrm{ECe}$ values ranged from 17.0 to $104.0 \mathrm{dsm}^{-1}$. Total Calcium carbonate content varied from 0.35 to $8.7 \%$ without distribution pattern with soil depths. Organic matter content was very low and varied from 0.1 to $1.2 \%$. Gypsum content was very low not exceeds $2.8 \%$ CEC values ranged from 1.4 to $4.1 \mathrm{C}$ mole $\mathrm{Kg}^{-1}$. ESP varied from 6.3 to $12.7 \%$ indicating non-sodic status.

\section{Soil of Elevated Sand Dunes:}

The elevated sand dunes geomorphic unit covers a relatively large area. It is composed of mobile elevated crescent shabed sand dunes. It extended from Suez Canal in the west to Wadi El-Arish in the east. Topographically their terrains are rough and high with Maximum elevation of $+12 \mathrm{~m}$ in some places. The lower parts of dune slopes are occupied by few scattered palm tree communities.

The soils of this unit were represented by three soil profiles (6, 7 and 8). These soils have severe undulating topography dominated by aeolian sand deposits in the form of dunes, hummocks and sheets. Data in Tables (1 and 2) show that, the soil dry color varied from gray (10 YR 5/1) to very pale brown (10 YR 7/3). While moist color ranged between gray (10YR 5/1) and every pale brawn (10YR 7/4). Soil texture is sand throughout profiles depths. Soil reaction is moderately to very strongly alkaline as indicated by $\mathrm{pH}$ values which ranged from 8.2 to 9.2. The soils are non to slightly saline as indicated by ECe values which ranged from 0.2 to $6.2 \mathrm{dsm}^{-1}$. Organic matter content is very low and does not exceed $0.3 \%$. $\mathrm{CaCo}_{3}$ content is commonly low and ranges from 0.5 to $4.4 \%$ with no specific distribution pattern with depth. Gypsum content ranged between 0.1 and $0.5 \%$. CEC values are low and ranged from 0.8 to $2.2 \mathrm{C}$ mole $\mathrm{kg}^{-1}$. ESP values were less than $15 \%$ indicating nonsodic soils.

\section{Soils of El-Tina plain:}

El-Tina plain geomorphic unit extends for about $75 \mathrm{~km}$ long with about $25 \mathrm{~km}$ width in the northwest direction of Sinai. This plain is generally lower than the surrounding areas, mostly exists near the present sea level. The surface is sometimes covered with low sand dunes, sand accumulation or loessy hummocks. El-Tina plain exhibits different subunits, namely El-Tina bay and El-Tina mud flat. El-Tina bay is gulf at the western Sinai coast between Port Said and ElBardawil lake. El-Tina mud flat occupies the north western corner of El-Tina plain with a triangular shape. It is dominated by highly saliferous clay, silt and sand materials. 
El-Tina plain geomorphic unit was represented by three soil profiles $(9,10$ and 11). Data in Tables (1) and (2) reveal that, the soil dry color varied from dark gray (10 YR 4/1) to light gray (10 YR 7/2). Whereas the moist color ranged from dark gray (10 YR 3/1) to gray (10 YR 6/1). The soils represented by profiles 10 and 11 have generally clay texture throughout the entire depths. The soils of profile (9) have sandy clay texture in the surface layers changed to lighter texture with depth. Organic matter content varied between 1.2 and $1.9 \%$ in the surface layers and decreased generally with depth. Calcium carbonate content varied from 0.5 to $6.2 \%$ Gypsum content ranged between 0.3 and $14.3 \%$. These soils have slightly alkaline reaction indicating from their $\mathrm{pH}$ values that varied from 7.1 to 7.7 . These soils are slightly to very extremely saline where ECe values ranged from 6.4 to 130.2 $\mathrm{dsm}^{-1}$. Cation exchange. Capacity varied

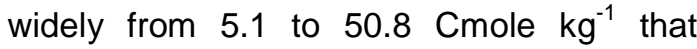
associated with the clay content. ESP values varied from 20.1 to $60.5 \%$ indicating sodicity affected soils.

\section{Western coastal plain:}

This unit extends from the Gulf of Suez on the south to near El-Kantra Shark on the north. It has generally low relief characterized by hills masses, sand planes, few short drainage lines and few Pliocene terraces. It has also number of lacks namely the Bitter laks and El-Timsah lake.

This geomorphic unit were represented by four soil profiles (12, 13, 14 and 15). Soil surface is gently to undulating and mainly covered with coarse sand with some boulders.
Data in Table (1) indicate that, these soils have pale brown color (10 YR 8/4) to yellow (10 YR 8/8) when dry and brownish yellow (10 YR 6/6) to yellow (10 YR 7/8) when moist. Data in table (2) show that, these soils have sand texture throughout the entire profiles depths. Soil reaction is moderately alkaline as indicated by $\mathrm{pH}$ values that ranged from 7.2 to 7.8 . These soils are very slightly to moderately saline as indicated by ECe values that ranged from 1.4 to 15.9 $\mathrm{dsm}^{-1}$. Organic matter content is low, ranged from 0.1 to $1.3 \%$ due to the prevailing aridity condition, and scattered vegetation.

Calcium carbonate content ranged from $1.16 \%$ to $8.9 \%$ Gypsum content varied from 0.1 to $25.5 \%$. CEC values varied from 1.2 to $8.7 \mathrm{C}$ mole $\mathrm{kg}^{-1}$. ESP values ranged from 7.9 to $12.6 \%$ indicating that these soils are nonsodic.

\section{Soil Classification:}

Based on the diagnostic criteria of Soil Survey Staff (2014), the studied soils are classified up to sub great group level underer Aridisols and Entisols orders (Table, 3). The soils represented by profiles 1,2 and 3 have a Salic horizon. These soils are classified as Typic Haplosalids. The soils of profiles 10 and 11 are also Haplosalids having a Gypsic horizon, therefore they classified as Gypsic Haplosalids. The soils represented by profiles 9, 12, 13 and 14 have a Gypsic horizon, therefore they classified as Typic Haplogypsids. The other soils of profiles 4 to 8 and 15 have not any diagnostic horizon and almost have sandy texture. These soils are affiliated to Entisols and classified as Typic Torripsamments, Table (3).

Table (3): Classification of the studied soils according to Soil Survey Staff (2014).

\begin{tabular}{|c|c|c|}
\hline Geomorphic Units & Profiles & Sub-great group classification \\
\hline Sabkha & $1,2,3$ & Typic Haplosalids \\
\hline Coastal plain & 4,5 & \multirow{2}{*}{ Typic Torripsamments } \\
\hline Elevated sand dunes & $6,7,8$ & Typic Haplogypsids \\
\hline El-Tina plain & 9 & Gypsic Haplosalids \\
\cline { 2 - 3 } & 10,11 & Typic Haplogypsids \\
\hline Western Coastal Plain & $12,13,14$ & Typic Torripsamments \\
\hline Western Coastal plain & 15 & \\
\hline
\end{tabular}


Land Evaluation:

I. Evaluation of Land suitability for irrigated Agriculture.

Quantitative estimation of soil characteristics namely, topography, wetness, texture, soil depth, $\mathrm{CaCO}_{3}$, gypsum and salinity and sodicity were used for evaluating land suitability index according to Sys and Verhey (1978). The soils could be placed into grades according to their calculated suitability indexes (Ci) as the following criteria:

\begin{tabular}{|c|c|c|c|}
\hline $\begin{array}{c}\mathrm{Ci} \\
(\%)\end{array}$ & Order & Class & Soil grade \\
\hline $\begin{array}{l}75- \\
100\end{array}$ & \multirow{3}{*}{ S } & S1 & Highly suitable \\
\hline $\begin{array}{l}50- \\
<75\end{array}$ & & S2 & Moderately suitable \\
\hline $\begin{array}{l}25- \\
<50\end{array}$ & & S3 & Marginally Suitable \\
\hline \multirow[b]{2}{*}{$<25$} & \multirow[b]{2}{*}{$\mathrm{N}$} & N1 & Currently not suitable \\
\hline & & N2 & $\begin{array}{l}\begin{array}{l}\text { Permanently } \\
\text { suitable }\end{array} \\
\text { not }\end{array}$ \\
\hline
\end{tabular}

The suitability indexes were calculated for current suitability (CS) of the studied soils with their present situation and for potential suitability (PS) of the soils when their limitation could be corrected as presented in Table (4).

\section{Current land suitability}

Data in Table (4) indicated that, there are two suitability classes and grades of the studied soils in their present situation i.e. marginally suitable (S3) and non-suitable (N) as follows:

Marginally suitable soils (S3): are the soils of profiles and 6, 7 and 8 (Elevated sand dunes), 9 and10 (El-Tina Plain); 12, 13 and 15 (western coastal plain). These soils are suffering mainly from texture, $\mathrm{CaCO}_{3}$ and wetness limitations with different severity. They have suitability index (Ci) values between 26.0 and 32.8 .

Non-suitable soils $(\mathbf{N})$ : are the soils of Sabkha and Coastal plain units in addition to the soils of profiles 11 (El-Tina plain) and 14 (Western coastal plain). These soils have suitability index $(\mathrm{Ci})<24.0$. The main limiting parameters are the sandy texture, soil depth, salinity and wetness.

\section{Potential land suitability}

The severity of limitations in the marginally suitable soils $\left(S_{3}\right)$ and some of not suitable soils $(\mathrm{N})$ could be corrected and reduce their effects by leaching of salts, addition of organic manures and texture ameliorators, construction of drainage system and apply a modern irrigation system. Accordingly, the suitability evaluation of these soils could be improved as follows (table, 4):

Moderately suitable soils (S2): This class could be contain the soils of El-Tina plain (profiles 9, 10 and 11) with potential suitability $(\mathrm{Ps})$ index $(\mathrm{Ci})$ values between 62.8 and 72.2 .

Marginally suitable soils (S3) : This class could be contain the soils of profile 1 from (Sabkha); 4 and 5 (Coastal plain); and all profiles (6 to 8 ) of Elevated sand dunes as well as profiles (12 to 15) of Western Coastal plain. These soils have potential suitability (Ps) index (Ci) values between 25.5 and 34.2 (Table, 4).

\section{Evaluation of soil suitability for growing some main crops}

Studied soils were evaluated to determine their suitability for growing 15 field, vegetable and fruit crops according to Sys et al. (1993). The obtained data are presented in Table (5) as both of current and potential suitability.

\section{Current suitability for crops :}

Date in Table (5) reveal that the studied soils of Sabkha, El-Tian plain and Western coastal plain in their present situation are not suitable for growing most of chosen crops. Few crops are marginally suitable such as alfalfa, barley and olives in El- Tian plain soils as well as wheat, watermelon and olives in Western Coastal plain soils. 


\begin{tabular}{|c|c|c|c|c|c|c|c|c|c|c|c|c|c|c|c|c|}
\hline \multirow{2}{*}{$\begin{array}{l}\text { 总 } \\
\text { 莺 } \\
\overline{\overline{5}}\end{array}$} & $\begin{array}{l}\text { in } \\
\text { an }\end{array}$ & 8 & $\frac{N}{2}$ & $\frac{N}{z}$ & $\mathscr{8}$ & $\bar{~}$ & 8 & 8 & $\mathscr{~}$ & ชี & ชิ & ஸิ & 83 & 8 & 8 & 8 \\
\hline & 8 & $z$ & $z$ & $z$ & $z$ & $z$ & 8 & 83 & 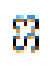 & 8 & $\mathscr{~}$ & $z$ & 82 & $\tilde{\wp}$ & $z$ & 83 \\
\hline \multirow{2}{*}{ 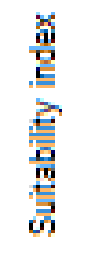 } & in & ले & ชิ & $E$ & $\begin{array}{l}\text { 号 } \\
\text { 号 }\end{array}$ & $\begin{array}{l}\text { 电 } \\
\text { 恕 }\end{array}$ & ले & ले & $\stackrel{\circ}{\circ}$ & $\begin{array}{l}\text { क्g } \\
\text { gi }\end{array}$ & 岕 & $\begin{array}{l}\mathscr{8} \\
\tilde{~} \\
6\end{array}$ & $\begin{array}{l}8 \\
\text { से }\end{array}$ & $\begin{array}{l}\text { 울 } \\
\text { 람 }\end{array}$ & $\begin{array}{l}\text { 今̛ } \\
\text { 岂 }\end{array}$ & 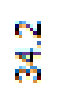 \\
\hline & in & 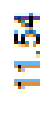 & $\begin{array}{l}\text { io } \\
\% \\
\%\end{array}$ & $\frac{9}{9}$ & $\begin{array}{l}\text { लै } \\
\text { 으 }\end{array}$ & 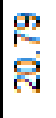 & $\begin{array}{l}\mathscr{W} \\
\text { N }\end{array}$ & लू & $\begin{array}{l}\text { مै } \\
\text { مे }\end{array}$ & $\frac{9}{\dot{m}}$ & $\begin{array}{l}\overline{0} \\
\text { '্ं }\end{array}$ & $\begin{array}{l}\mathscr{B} \\
\mathbb{X}\end{array}$ & 点 & लि & 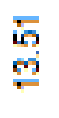 & $\begin{array}{l}\infty \\
\stackrel{5}{\circ} \\
\stackrel{8}{\circ}\end{array}$ \\
\hline \multirow{2}{*}{ 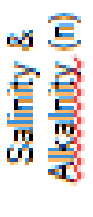 } & $\begin{array}{l}\vdots \\
\text { in }\end{array}$ & 8 & 8 & 음 & 웅 & 은 & 8 & 8 & 음 & 음 & 은 & 8 & 8 & 8 & 8 & 8 \\
\hline & in & แ & 오 & ณ & 8̊ & 票 & \% & \% & 8) & 8 & 웅 & 웅 & क & 운 & 뺑 & 8 \\
\hline \multirow{4}{*}{ 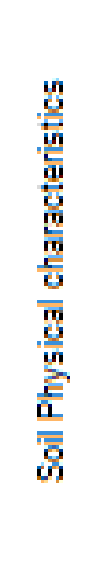 } & 통 & 8 & א & 8 & 8 & 8 & 8 & 8 & 8 & '多 & 8 & 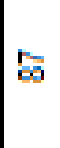 & 8 & 음 & $R$ & \$ి \\
\hline & 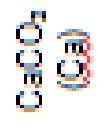 & 18 & 18 & 18 & 岁 & 岁 & 通 & 通 & 哭 & 8 & 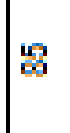 & $\mathscr{2}$ & 뼝 & 영 & 孚 & 通 \\
\hline & 吉司 & 8ิ & 8 & ณ & $\stackrel{\mathscr{L}}{\sim}$ & $\stackrel{\varrho}{\stackrel{2}{2}}$ & 8 & 음 & 8 & 8 & 음 & 8 & 8 & 응 & 8) & 8 \\
\hline & 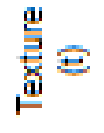 & 웅 & 웅 & 웅 & 웅 & 웅 & 웅 & 웅 & 웜 & 8 & 명 & 峞 & 웅 & 웅 & 웅 & 웡 \\
\hline \multicolumn{2}{|c|}{ 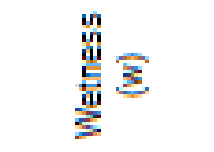 } & $\stackrel{2}{2}$ & 운 & 8 & 8) & 8 & 8 & 8 & 음 & $\stackrel{2}{2}$ & 8 & 8 & 岑 & 总 & 음 & 8 \\
\hline \multirow{2}{*}{ 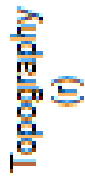 } & in & 은 & 으 & 8 & 8 & 음 & 음 & 8 & 음 & 8 & 8 & 음 & 응 & 8 & 8 & 8 \\
\hline & in & 8. & \$ & 웅 & 음 & 迢 & 음 & 8 & 웅 & 음 & 음 & 음 & 8 & 응 & ৪ & 음 \\
\hline \multicolumn{2}{|c|}{ 竞 } & $=$ & $N$ & $m$ & v & (6) & $\omega$ & $r$ & $\infty$ & क & 으 & $=$ & $\cong$ & 9 & \pm & 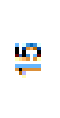 \\
\hline \multicolumn{2}{|c|}{ 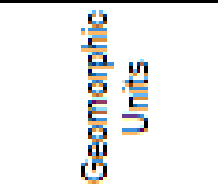 } & \multicolumn{2}{|c|}{ 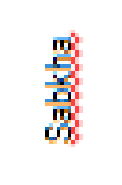 } & \multicolumn{3}{|c|}{ 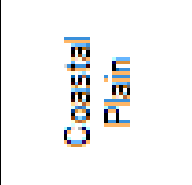 } & \multicolumn{3}{|c|}{ 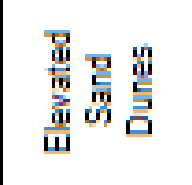 } & \multicolumn{3}{|c|}{ 旁点 } & \multicolumn{4}{|c|}{ 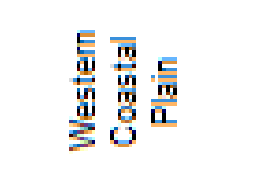 } \\
\hline
\end{tabular}




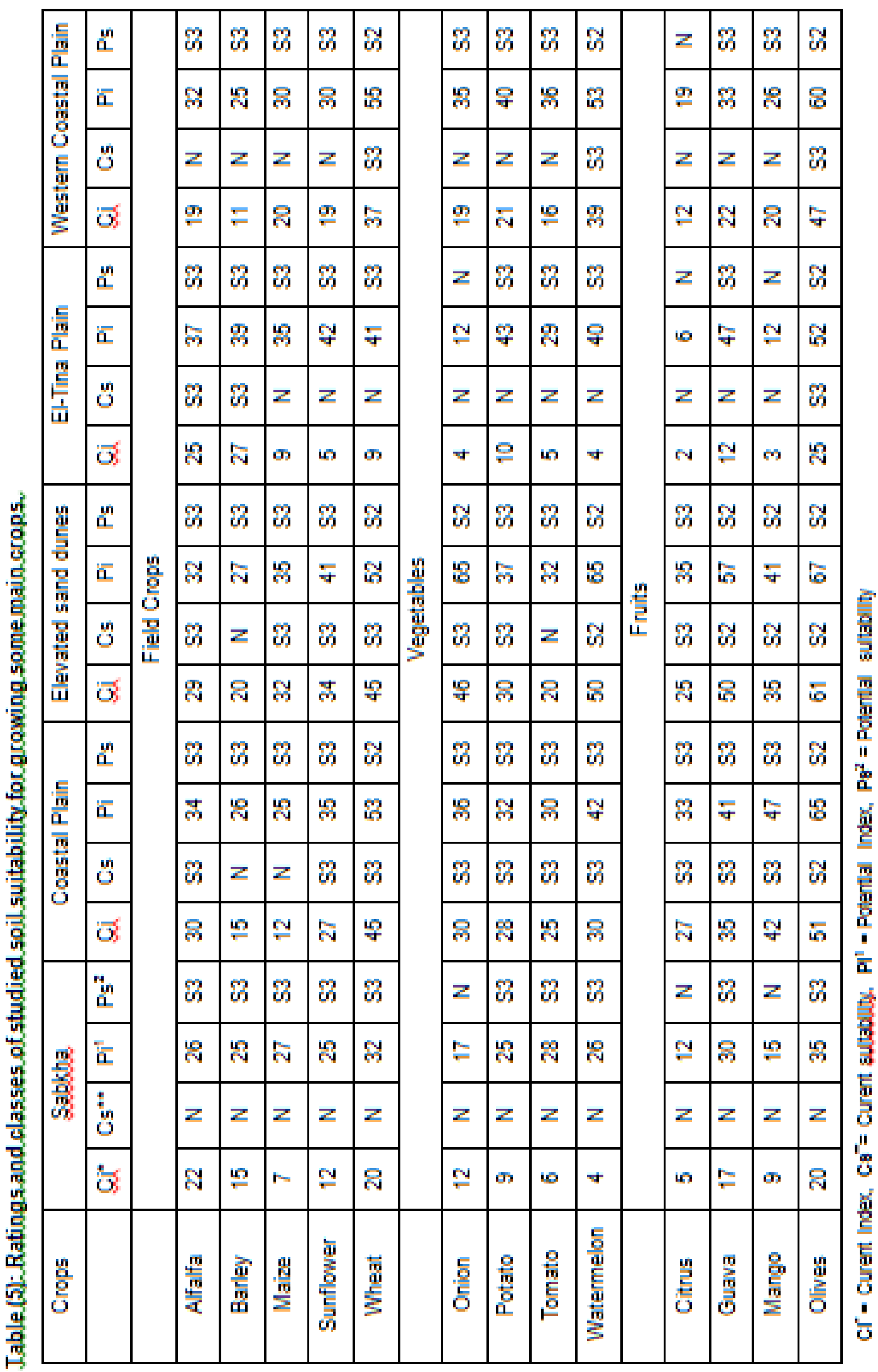


On the other hand, most of these crops are marginally suitable S3 for growing in the soils of Coastal plain and Elevated sand dunes. Some of crops are moderately suitable (S2) for growing in Elevated sand dunes such as watermelon, guava, mango and olives.

\section{2- Potential suitability for crops:}

A proper fertilization and management associated with intensive leaching, efficient drainage and modern irrigation systems could be improved the suitability of the most studied crops for growing in all studied soils (Table, 5). Only few crops exhibited not suitability for growing in some soils such as onion, citrus and mango in Sabkha and ElTina plaint soils.

\section{REFERENCES}

Dames and Moore, (1985). Water Supplies and costs vol. V Sinai Development Study. Phase. I. Final Report submitted to the Ministry of Development, Egypt.

FAO, (1976). A frame worke for land evaluation FAO soils Bulletin No, 32, Rome.

FAO, (2006). Guide lines for Soil Profile description, FAO. ISRIC. Publication, Rome.
Henry and Chorowicz, (1987). Geological and geomorphological remote analysis map: $\quad 500.000$ Landsat imagery interpretation, institute Fraucais $\mathrm{du}$ Petrole.

Said R. (2000). The Geology of Egypt. Elsevier Publishing Company, New York, U.S.A.

Sys, C. and Verheye, W. (1978). An attempt to the evaluation of physical land characteristics for irrigation agriculture according to the FAO framework for land evaluation in Train, Ghent. For post Graduate of soil science, Ghent, Belgium.

Sys, C., E. Van, J. Debavey and F. Bearaet (1993). Land Evaluation part III; Crops requirement. Agric. Public No. 7, Ghent, Adm. for Dev. Coop. Brussels, Belgium.

Burt, Rebecca. Ed., (2004). Soil Survey Laboratory Methods Manual, Soil Survey Investigations Report No. 42, Version 4, USDA, NRES, Lincoln, Nebraska.

Soil Survey Staff, (2014). Keys to Soil Taxonomy, the $\left(12^{\text {th }}\right)$ edition, USDA NRCS, Lincoln, Nebraska. 
تقسيم وتقييم الأراضي الممثلة للوحدات الجيومورفولوجية

في الساحل الثمالي الغزبي لثبه جزيرة سيناء - مصر الهر

غادة عبد العزيز عبد القادر

معهة بحوث الأراضي والمياه والبيئة مركز البحوث الزراعية - الجيزة

الملخص العربي

تعتبر أراضي الساحل الثمالي الغربي لثبه جزيرة سيناء أحد المناطق المستهدفة للتوسع الزراعي في مصر

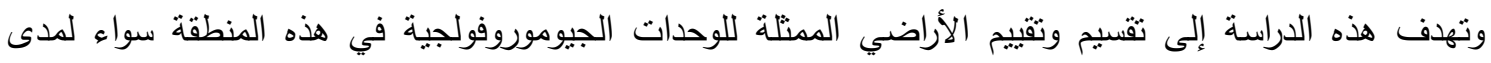
وملاءمتها للاستغلال الزراعي وكنلك لزراعة بعض التهائ الكحاصيل الرئيسية الهامة.

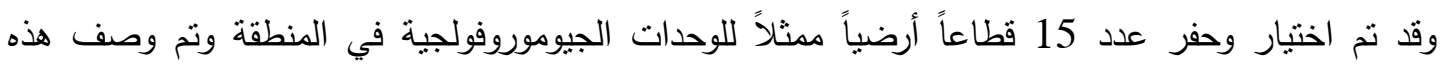

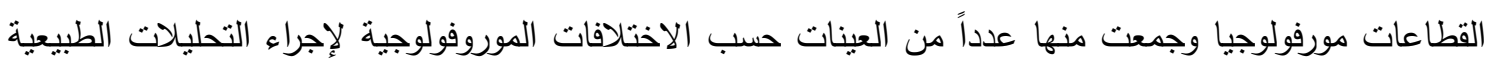
والكيميائية يمكن تلخيص نتائج الدراسة فيما يلي:

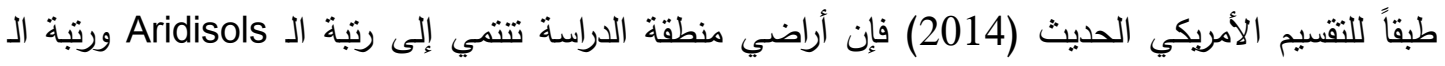
Entisols

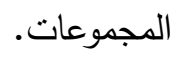

وتوضح نتائج تقيم ملائمة هذه الأراضي للاستغلال الزراعي إلى انتمائها إلى رثبتي الأراضي الهامشية

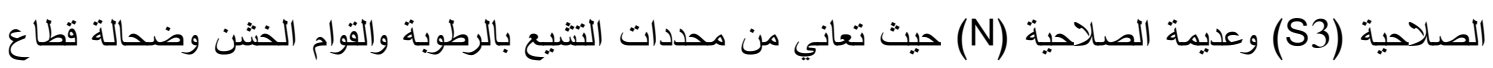

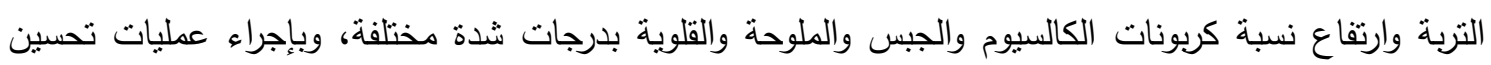

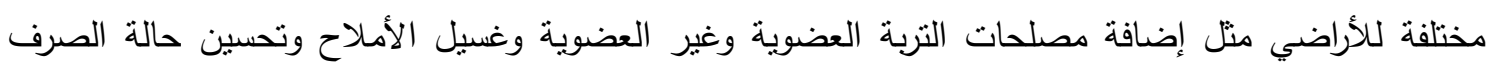

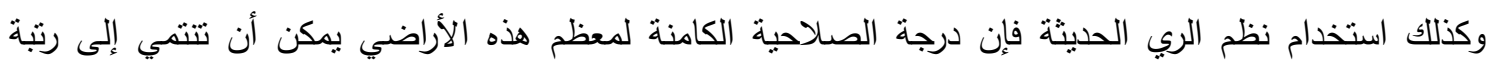
متوسطة الصلاحية (S2) وهامثية الصلاحية (S3).

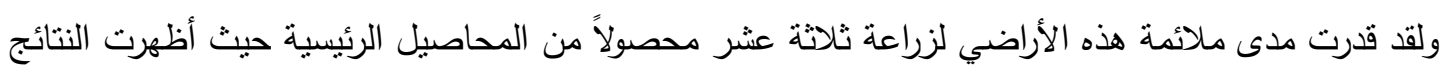

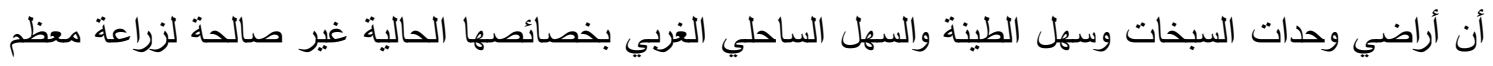

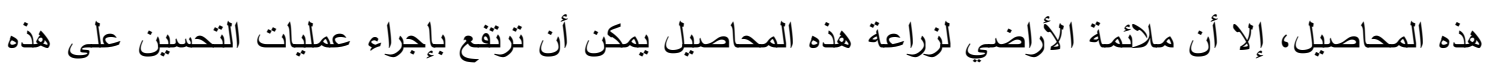
الأراضي. 